\title{
STUDY OF FLAME RESISTANCE FOR ADDITIVES - CONTAINING EPOXY AND POLYESTER
}

\author{
https://doi.org/10.32792/utq/utj/vol10/4/1
}

\author{
Mohammed Hallol Mokhilif \\ University of THI- QAR \\ College of education For pure sciences
}

\begin{abstract}
:
In this paper, additives dechlorane plus which used synergistically with sodium-orthophosphate and with alumina, sodium-orthophosphate, and alumina have been used as a flame retardants for unsaturated polyester and epoxy resin. The additives were used at low and high levels with unsaturated polyester and they were used at high levels with epoxy resin .At low levels, the additives were used in weight percentages of $(1,3,5,7$ and 10)\%,At high levels ,They were used in weight percentages of $(15,20,25,30$ and 35$) \%$.Hand -lay up was used to prepare the specimens. The paper showed that the additives have good effectiveness in reducing the burning at high weight percentages and they appeared high effectiveness in resisting the flame when they were used as a synergistic flame retardants.
\end{abstract}

Keyword: unsaturated polyester, epoxy resin, flame retardants, synergism.

\section{1- Introduction:}

Epoxies and polyesters are studied for use in many applications such as aircraft because they have a number of properties ,These properties include: exellent mechanical properties ,low cost and ease of processing [1].Thermosetting polymers have high flammability when they exposed to fire. Flammability of thermoset resein was shown in the following comparison [2] :

Vinylester and unsaturated polyester $>$ Epoxy $>$ Bismaleimide $>$ Polymide $>$ Phenolic

The fire resistance of these polymers can be improved by incorporating of flame retardants into polymeric materials as an additive and as apart of the polymeric chain . Flame retardants resistant the fire during the degradation or after ignition [3].Phosphorus was incorporated within the backbone of the epoxy resin and not used an additives [4]. Many studies were achieved in the field flame retardance of polymers; Ngakan et al studied used diammonium phosphates(DAP) to resistance flammability of thermoplastic reinforced with natural fibers [5]. Charuchinda et al used sodium polyphosphate and chitosan to improve the durability of the flame retardance in the cotton fabric and increasing the LOI(Limiting oxygen index) values from 17 to 19 when compared to the untreated cotton fabric[6 ].HOH et al used dechlorance plus (DP) as a chlorinated flame retardant in grand lakes[7].Simon Ningsun Zhou et al used dechlorance plus (DP) ,dechlorance 602 , dechlorance 603 and dechlorance 604 as a flame retardants in humans[8]. Edward d.Weil et al used dechlorane plus in law smoke formulations ,They use dechlorane plus and 5-10\% Antimony oxide as synergist with polymide 6 and glass reinforced polymide 6 ,they used dechlorane plus with glass reinforced polymide 66[9].Robin 


\section{University of Thi-Qar Journal Vol.10 No.4 Dec 2015}

Web Site: https://jutq.utq.edu.iq/index.php/main Email: journal@jutq.utq.edu.iq

J. LAW et al used dechlorane plus and 17 brominated diphenyleether (BDE) as a flame retardant in the blubbere of harbor[10].Minodora Leca et al used ammonium phosphate , ammonium polyphosphate and alumina trihydrated with law sodium with melamine as a fire retardant coatings [11].Joseph et al employed phosphorus as areactive component with epoxy and study the flammability and mechanical properties of the samples[12].Patrick Lim et al found that the flammability performance of intumescent ammonium polyphosphate (APP) filled epoxy/glass fibers composites is better compared with melamine cyanurate (MC) [13].

\section{2- Methodology and sample preparation:}

The

2-1 Materials:

polymers used in this study include : Epoxy resin and polyester resin. Three types of additives were used as the flame retardants for polymers These additives are : Sodiumorthophosphate Na3PO4 (supplied from BRITISH house dunags B.D.H in powder form as shown in Figure A), Dechlorance plus C18H12Cl12 (supplied from GERMANY in powder form as shown in Figure $\mathrm{C}$ ) and Alumina Al2O3 ( in powder form as shown in Figure B )

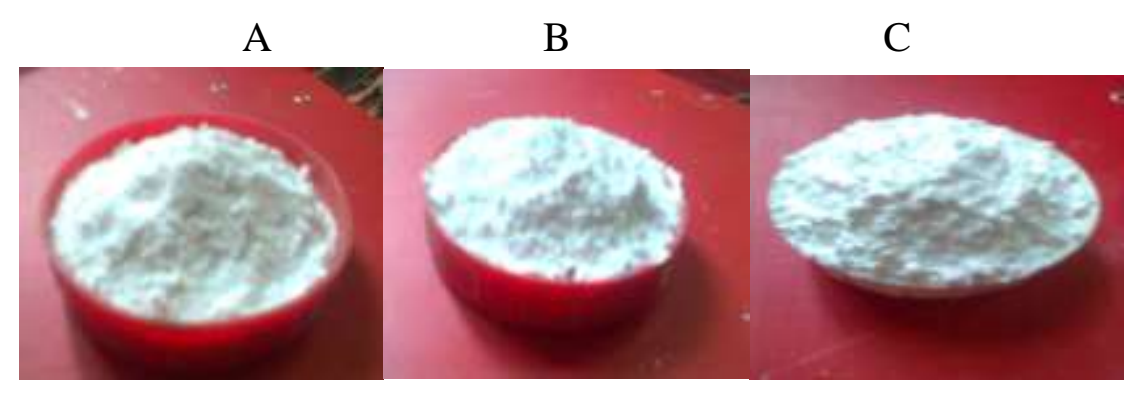

Figure(1) A)Sodium-orthophosphate Na3PO4

B) Alumina $\mathrm{A} 12 \mathrm{O} 3$

C) Dechlorane plus $\mathrm{C} 18 \mathrm{H} 12 \mathrm{Cl12}$

\section{2 -2 Samples preparation:}

The samples from polyester and epoxy resin with every additive and with sodiumorthophosphate/dechlorance plus and alumina /dechlorance plus synergistically were prepared.The cast speciments was used in dimensions $(15 \mathrm{~cm} \times 15 \mathrm{~cm} \times 0.3 \mathrm{~cm})$. The test specimens were cut in dimensions $(12.5 \mathrm{~cm} \times 1.3 \mathrm{~cm} \times 0.3 \mathrm{~cm})$.

2-3Determination methods:

The flammability of polyester and epoxy with the additives was determined according to ASTM D635 method .In this method, the sample is ignited in horizontal position with flame. The flame is removed after $30 \mathrm{sec}$ and the sample is allowed to burn, if the flame speed 
continues beyond $10 \mathrm{~cm}$ the burning rate is reported ,if the flame extinguishing was occurred before the flame reaches the $10 \mathrm{~cm}$ mark the time of extinguish and the burned distance are reported, then the rate of burning is reported in this case , the sample has self - extinguish, if the flame extinguishes after removing the flame ,Not burning of the sample is reported[14 ].

\section{3- RESULTS AND DISCUSSION:}

Test results for the additives with unsaturated polyester at low weight percentages are shown in Tables : ( 1-5) and Figure ( 2), They showed that the additives don't affect as a flame resistance and they appeared low degree of flame retardancy to polymers when they were used synergistically. At high weight percentages with unsaturated polyester and epoxy resin, the additives impact high degree of flame retardancy to the polymers as shown in Tables : (6-15) and Figures:(3) and (4) . Among the three classes of additives, the dechlorance plus appeared to be the most effective flame retardant, dechlorane plus caused flame extinguishment at $30 \%$ ratio and not burning at $35 \%$ ratio with unsaturated polyester, it caused not burning at $30 \%$ ratio with epoxy . Sodium orthophosphate and alumina led to self - extinguishing at $35 \%$. The addition of flame retardants synergistically to the polymers appeared high efficiency in reduce flammability of polymers. It can be seen from variation of flame spread with weight percentages of additives that the synergistic effect of sodium orthophosphate with dechlorance plus caused auto - extinguishment at $25 \%$ ratio with unsaturated polyester and at $20 \%$ ratio with epoxy . Not burning occurred at $30 \%$ ratio with unsaturated polyester and at $25 \%$ ratio with epoxy . It is noted that the self - extinguishing occurred at $35 \%$ ratio when dechlorance plus and alumina were used synergistically with polymers. Phosphorus compounds and halogen flame retardants act in the condensed phase by promoting the formation of carbonaceous char and in the gaseous phase by diluting the flammable gases [15]. During combustion of polymers the Alumina remain in condensed phase and forms a protective barrier on the polymer surface, shield it against further decomposition [16].

\section{Table (1) Rate of burning (R.B) test for UPE with Sodium-orthophosphate}

\begin{tabular}{|l|c|c|c|c|c|c|}
\hline Additive $\%$ & $0 \%$ & $1 \%$ & $3 \%$ & $5 \%$ & $7 \%$ & $10 \%$ \\
\hline R.B cm/ min & 3.219 & 3.00 & 2.927 & 2.792 & 2.629 & 2.586 \\
\hline AEB cm & 10 & 10 & 10 & 10 & 10 & 10 \\
\hline
\end{tabular}

Extent of Burning

$\mathrm{AEB}=$ Average

T able (2) Rate of burning (R.B) test for UPE with Dechlorance plus

\begin{tabular}{|l|c|c|c|c|c|c|}
\hline Additive $\%$ & $0 \%$ & $1 \%$ & $3 \%$ & $5 \%$ & $7 \%$ & $10 \%$ \\
\hline R.B cm/ min & 3.219 & 2.898 & 2.799 & 2.790 & 2.567 & 2.469 \\
\hline AEB cm & 10 & 10 & 10 & 10 & 10 & 10 \\
\hline
\end{tabular}

Extent of Burning 
University of Thi-Qar Journal Vol.10 No.4 Dec 2015

Web Site: https://jutq.utq.edu.iq/index.php/main Email: journal@jutq.utq.edu.iq

Table (3) Rate of burning (R.B) test for UPE with Alumina

\begin{tabular}{|l|c|c|c|c|c|c|}
\hline Additive $\%$ & $0 \%$ & $1 \%$ & $3 \%$ & $5 \%$ & $7 \%$ & $10 \%$ \\
\hline R.B cm/ min & 3.219 & 2.940 & 2.927 & 2.768 & 2.564 & 2.540 \\
\hline AEB cm & 10 & 10 & 10 & 10 & 10 & 10 \\
\hline
\end{tabular}

Extent of Burning

$\mathrm{AEB}=$ Average

Table (4) Rate of burning (R.B) test for UPE with ( Sodium-orthophosphate + Dechlorance plus)

\begin{tabular}{|l|c|c|c|c|c|c|}
\hline Additive $\%$ & $0 \%$ & $1 \%$ & $3 \%$ & $5 \%$ & $7 \%$ & $10 \%$ \\
\hline R.B cm/ min & 3.219 & 2.422 & 2.362 & 2.351 & 2.213 & 2.190 \\
\hline AEB cm & 10 & 10 & 10 & 10 & 10 & 10 \\
\hline
\end{tabular}

$\mathrm{AEB}=$ Average Extent of Burning

Table (5) Rate of burning (R.B) test for UPE with (Dechlorance plus + Alumina)

\begin{tabular}{|l|c|c|c|c|c|c|}
\hline Additive\% & $0 \%$ & $1 \%$ & $3 \%$ & $5 \%$ & $7 \%$ & $10 \%$ \\
\hline R.B cm/ min & 3.219 & 2.440 & 2.385 & 2.342 & 2.297 & 2.196 \\
\hline AEB cm & 10 & 10 & 10 & 10 & 10 & 10 \\
\hline
\end{tabular}

Average Extent of Burning

$\mathrm{AEB}=$

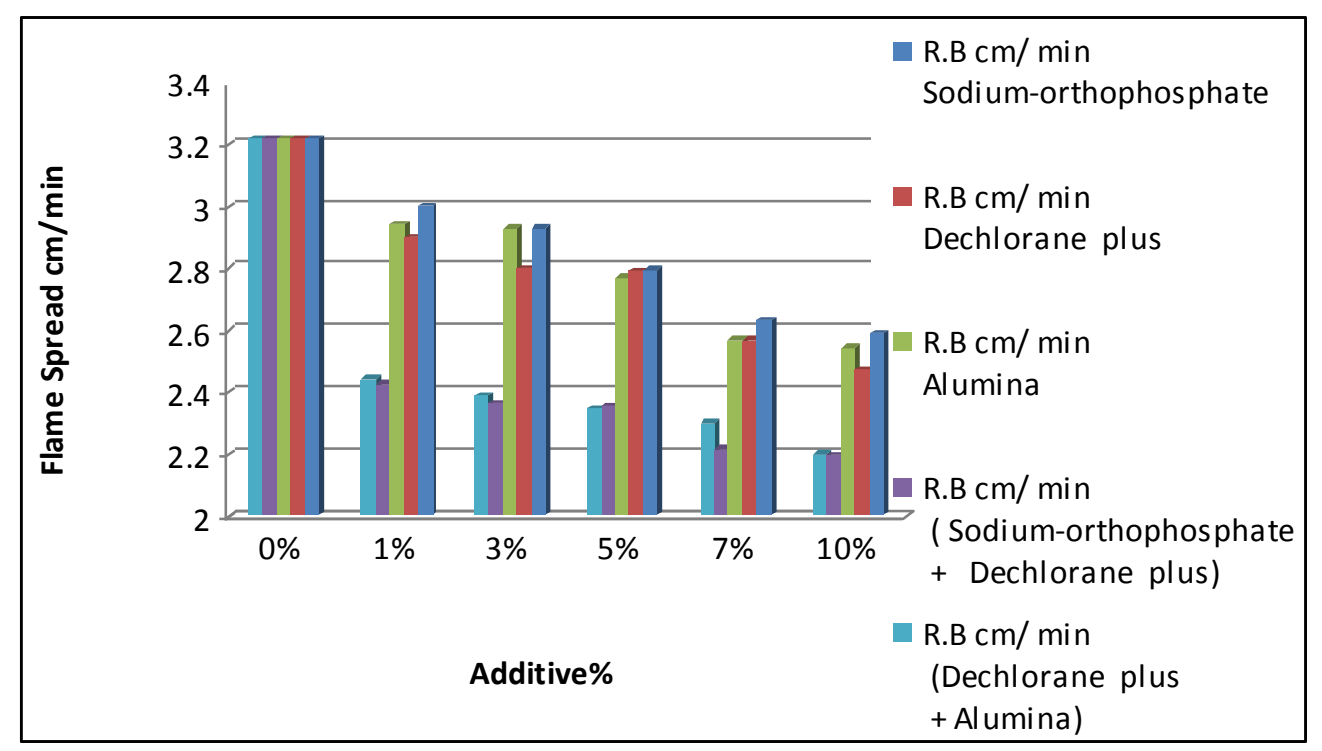


University of Thi-Qar Journal Vol.10 No.4 Dec 2015

Web Site: https://jutq.utq.edu.iq/index.php/main Email: journal@jutq.utq.edu.iq

Figure(2) Variation of flame spread with Weight percentages of additives For UPE

Table (6) Rate of burning (R.B) test for UPE with Sodium-orthophosphate

\begin{tabular}{|c|c|c|c|c|c|c|}
\hline Additive $\%$ & $0 \%$ & $15 \%$ & $20 \%$ & $25 \%$ & $30 \%$ & $35 \%$ \\
\hline R.B cm/min & 3.219 & 2.575 & 2.186 & 2.020 & 1.844 & 0.714 \\
\hline AEB cm & 10 & 10 & 10 & 10 & 10 & $1.4($ S.E) \\
\hline
\end{tabular}

S.E $=$ self extinguishing

Table (7) Rate of burning (R.B) test for UPE with Dechlorance plus

\begin{tabular}{|c|c|c|c|c|c|c|}
\hline Additive $\%$ & $0 \%$ & $15 \%$ & $20 \%$ & $25 \%$ & $30 \%$ & $35 \%$ \\
\hline R.B cm $/ \mathrm{min}$ & 3.219 & 2.229 & 1.708 & 1.456 & 1.383 & - \\
\hline AEB cm & 10 & 10 & 10 & 10 & 10 & N.B \\
\hline
\end{tabular}

$\mathrm{N} . \mathrm{B}=$ not burning

Table (8) Rate of burning (R.B) test for UPE with Alumina

\begin{tabular}{|c|c|c|c|c|c|c|}
\hline Additive $\%$ & $0 \%$ & $15 \%$ & $20 \%$ & $25 \%$ & $30 \%$ & $35 \%$ \\
\hline R.B cm $/ \mathrm{min}$ & 3.219 & 2.419 & 1.969 & 1.699 & 1.468 & 1.315 \\
\hline AEB cm & 10 & 10 & 10 & 10 & 10 & $5(\mathrm{~S} . \mathrm{E})$ \\
\hline
\end{tabular}

S.E = self extinguishing

Table (9) Rate of burning (R.B) test for UPE with ( Sodium-orthophosphate + Dechlorance plus)

\begin{tabular}{|c|c|c|c|c|c|c|}
\hline Additive $\%$ & $0 \%$ & $15 \%$ & $20 \%$ & $25 \%$ & $30 \%$ & $35 \%$ \\
\hline R.B cm $/ \mathrm{min}$ & 3.219 & 2.042 & 1.138 & 0.884 & - & - \\
\hline AEB cm & 10 & 10 & 4.5 (S.E) & 2.2 (S.E) & N.B & N.B \\
\hline
\end{tabular}

Table (10) Rate of burning (R.B) test for UPE with( Dechlorance plus + Alumina)

\begin{tabular}{|c|c|c|c|c|c|c|}
\hline Additive $\%$ & $0 \%$ & $15 \%$ & $20 \%$ & $25 \%$ & $30 \%$ & $35 \%$ \\
\hline R.B cm $/ \mathrm{min}$ & 3.219 & 2.137 & 1.792 & 1.350 & 1.140 & 0.487 \\
\hline AEB cm & 10 & 10 & 10 & 10 & 10 & 3 (S.E) \\
\hline
\end{tabular}

S.E $=$ self extinguishing 
University of Thi-Qar Journal Vol.10 No.4 Dec 2015

Web Site: https://jutq.utq.edu.iq/index.php/main Email: journal@jutq.utq.edu.iq

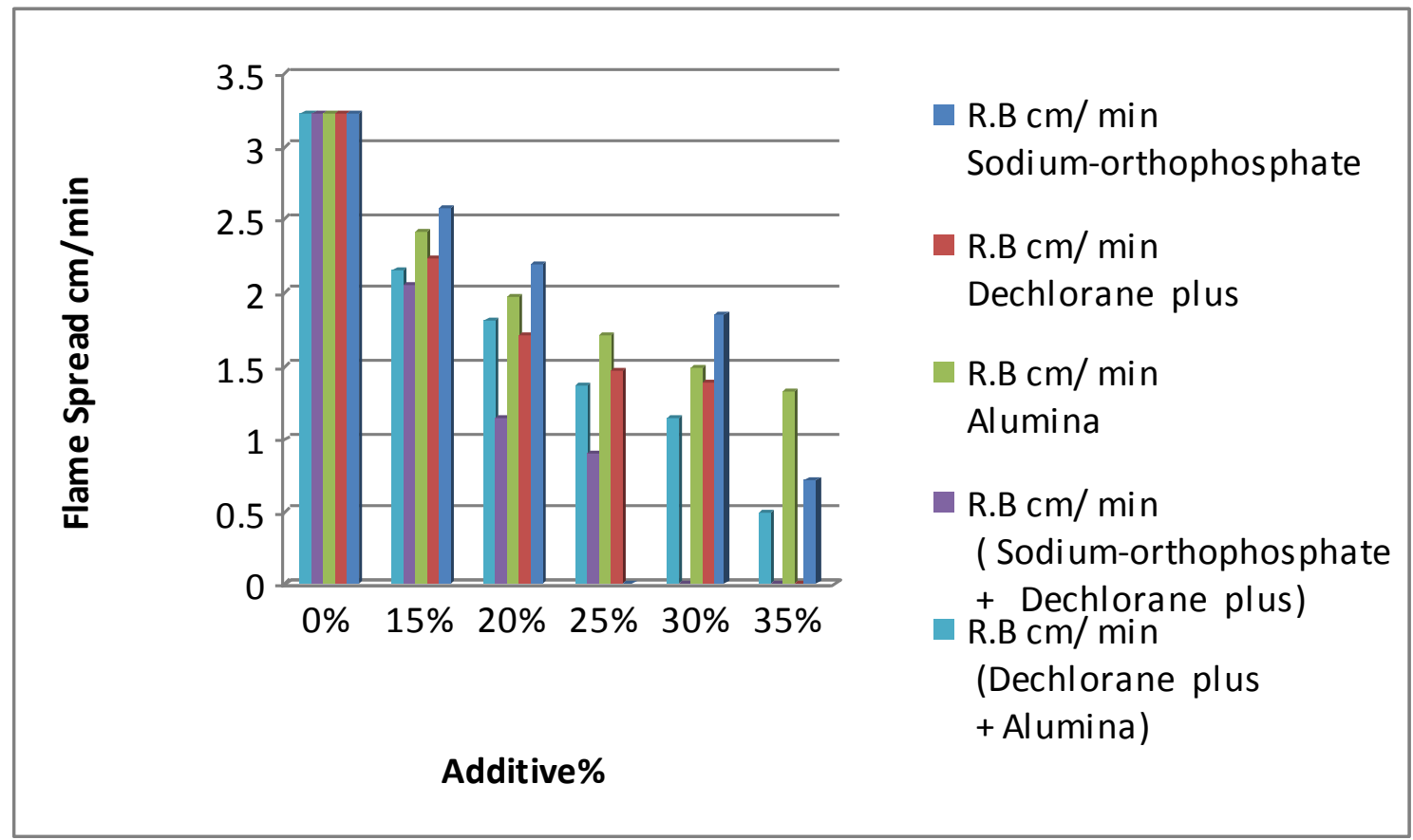

Figure(3) Variation of flame spread with Weight percentages of additives for UPE

Table (11) Rate of burning (R.B) test for EP with Sodium-orthophosphate

\begin{tabular}{|c|c|c|c|c|c|c|}
\hline Additive & $0 \%$ & $15 \%$ & $20 \%$ & $25 \%$ & $30 \%$ & $35 \%$ \\
\hline R.B cm/min & 2.631 & 2.524 & 1.985 & 1.753 & 1.627 & 0.325 \\
\hline AEB cm & 10 & 10 & 10 & 10 & 10 & 7 (S.E) \\
\hline
\end{tabular}

S.E = self extinguishing

Table (12) Rate of burning (R.B) test for EP with Dechlorance plus

\begin{tabular}{|c|c|c|c|c|c|c|}
\hline Additive & $0 \%$ & $15 \%$ & $20 \%$ & $25 \%$ & $30 \%$ & $35 \%$ \\
\hline R.B cm/min & 2.631 & 2.266 & 1.507 & 1.122 & - & - \\
\hline AEB cm & 10 & 10 & 10 & 10 & N.B & N.B \\
\hline
\end{tabular}

$\mathrm{N} . \mathrm{B}=$ not burning

Table (13) Rate of burning (R.B) test for EP with Alumina

\begin{tabular}{|c|c|c|c|c|c|c|}
\hline Additive & $0 \%$ & $15 \%$ & $20 \%$ & $25 \%$ & $30 \%$ & $35 \%$ \\
\hline R.B cm/min & 2.631 & 2.309 & 1.856 & 1.647 & 1.450 & 0.513 \\
\hline
\end{tabular}


University of Thi-Qar Journal Vol.10 No.4 Dec 2015

Web Site: https://jutq.utq.edu.iq/index.php/main Email: journal@jutq.utq.edu.iq

\begin{tabular}{|c|c|c|c|c|c|c|}
\hline AEB cm & 10 & 10 & 10 & 10 & 10 & 3.3 (S.E) \\
\hline
\end{tabular}

S.E $=$ self extinguishing

Table (14) Rate of burning (R.B) test for EP with (Sodium-orthophosphate + Dechlorance plus)

\begin{tabular}{|c|c|c|c|c|c|c|}
\hline Additive & $0 \%$ & $15 \%$ & $20 \%$ & $25 \%$ & $30 \%$ & $35 \%$ \\
\hline R.B cm/min & 2.631 & 1.777 & 0.437 & - & - & - \\
\hline AEB cm & 10 & 10 & 1.8 (S.E) & N.B & N.B & N.B \\
\hline
\end{tabular}

Table (15) Rate of burning (R.B) test for EP with (Dechlorance plus + Alumina)

\begin{tabular}{|c|c|c|c|c|c|c|}
\hline Additive & $0 \%$ & $15 \%$ & $20 \%$ & $25 \%$ & $30 \%$ & $35 \%$ \\
\hline R.B cm/min & 2.631 & 2.006 & 1.822 & 1.328 & 1.128 & 0.489 \\
\hline AEB cm & 10 & 10 & 10 & 10 & 10 & $3.6($ S.E) \\
\hline
\end{tabular}

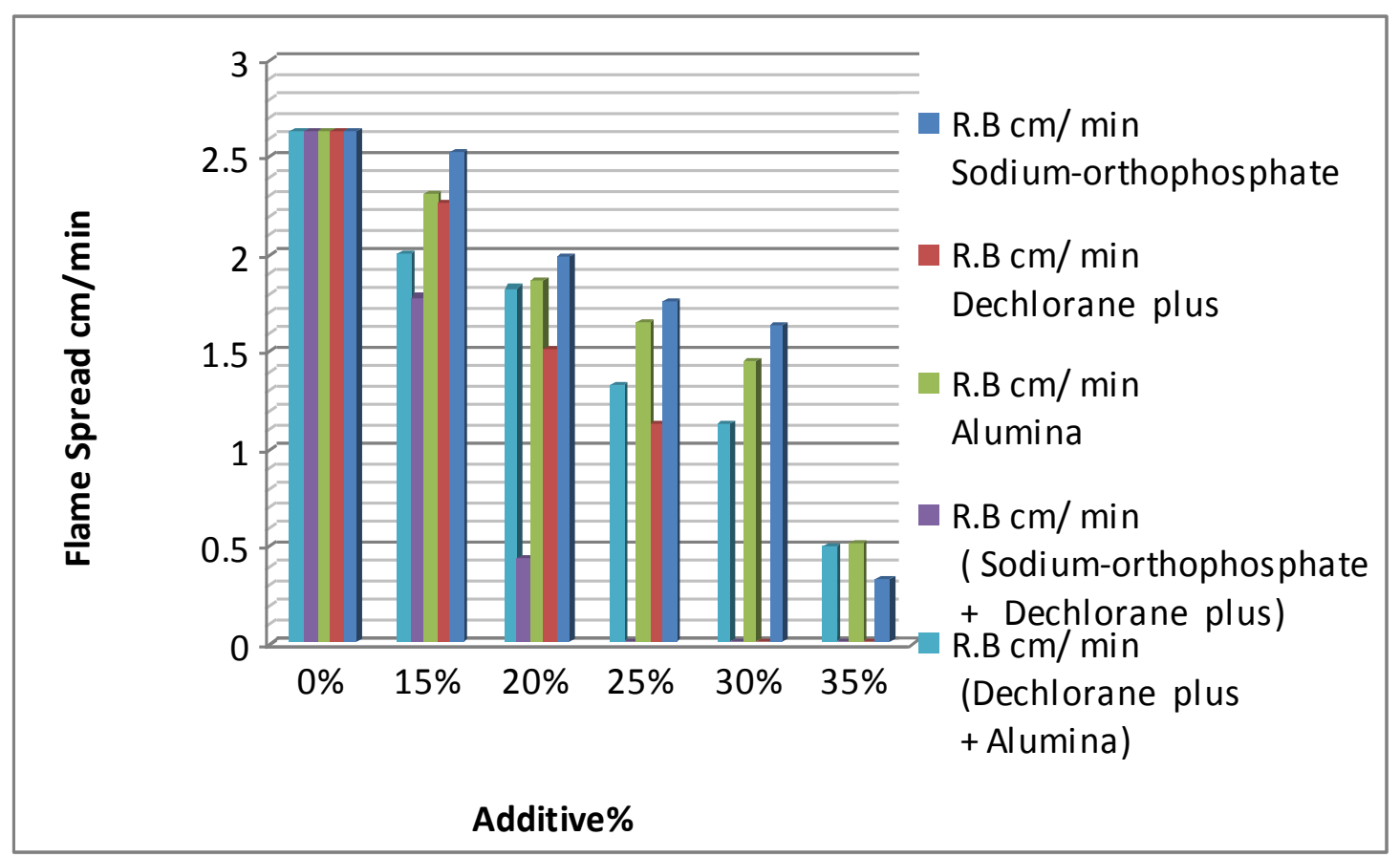

Figure (4) Variation of flame spread with weight percentages of additives for EP 


\section{4- conclusions :}

Good fire retardation was obtained from using the additives at high weight percentages, not burning occurred when dechlorane plus was used at weight percentage $35 \%$ with unsaturated polyester and at weight percentage $30 \%$ with epoxy. Hybrid additives-containing polymers performed high efficiency in resisting the flame. Self -extinguishing occurred when sodium orthophosphate and dechlorance plus were used synergistically at 20\% with UPE and EP , Not burning happened at $30 \%$ with UPE and at $25 \%$ with EP.

\section{References:}

1- RICHARD N .WALTERS , Fire- Resistant cyanate ester - Epoxy blends ,2002

2-TEJRAJ M. AMINABHAVI and PATRICK E.CASSIDY, Flammability Characteristics of Polymers ,polym.plast.Technol.Eng ,vol 28(7\&8) pp717$751,1989$.

3- CIU LIANA C .TESORO, Chemical Modification of Polymers with flame-retardant compounds, J.of polymer science: Macromolecular reviews, vol 13, pp283-353, 1978.

4- Dr.JURGEN H . TROITZSCH, Overiew of flame retardants , vol 16,pp1-18,1998.

5- NGUKAN PUTU GEDE SUARDANA, MIN SEUCK KU and JAE KYOO LIM ,Effect of diammonium phosphate on the flammability and mechanical properties of bio-composites, material and design, Vol32,1990- 1999, 2011.

6- SIREERAT CHARUCHINDA , KAWEE SRIKULKIT and THITIPORN MOWATTANA, co- application of sodium poly phosphate and chitosan to improve flame retardancy of cotton fabric ,J.sci .Ros ,Chula univ , Vol30,No1,2005.

7- HOH E. ,ZHU L. and HITES ,R.A. , Dechlorance plus ,a chlorinated flame retardant in the great lakes ,Environ, sci , technol, Vol40, No4, $1184-1189,2006$.

8- SIMON NINGSUN ZHOU, SHABANA SIDDIGUE, LAETISCRA LAROIE , LARISSA TAKSER ,NADIA ABDEL OUAHAB and JIPING ZHU ,Hexa chloronorbornene - based flame retardants in humans ,Vol66, pages 11-17,2014

9- EDWARD D. WEIL and SERGEI LEVCHIK, Current practice and recent commercial developments in flame retardancy of polyamides, J. of fire sciences ,Vol22,2004.

10- ROBIN J.LAW , SARA LOSADA, JONATHAN L.BARBER , PHILIPPE BERSUDER , ROB DEAVILLE, ABDREW BROWN LOW , ROD PENROSE and PAUL . JEPSON,Alternative flame retardants, dechlorane plus and BDEs in the blubber of harbour propoises stranded or by caught in the UK during 2008,Enveronment international, 60, pp81-88, 2013.

11- MINODORA LECA, LELIAN CIOROLANA, GOBRIELA CIOROLANA ,GABRIELA DAMIAN, CATALINACOS TEA andANA MARIA MATEI , Aqueous Ecological ntumescent Fire retardant coatings for multifunction application ,revue romaine de chemi , vol 52, No8, pp 745-752, 2007. 
Web Site: https://jutq.utq.edu.iq/index.php/main Email: journal@jutq.utq.edu.iq

12-PAUL M. HERGEN ROTHER, GRAIG M. THOMPSON , JOSEPH G. SMITH JR, JOHN W. CONNELL, JEFFREY A. HINKLEY, RICHARD E. LYON and RICHARD MOULTON ,Flammability of epoxy resins containing phosphorus , pp1-20,2007.

13-PATRICK LIM ,W.K , MARIATTI ,M ,CHOW ,W.S and MAR ,K.T,Halogen free retardants for epoxy substrate in electronic application, international electronic manufacturing technology conference ,2010.

14- A.H. LANDROCK : Handbook of plastics flammability and combustion technology ,Noyes publication , park ridge ,N,J ,1983.

15- BERNHARD SCHARTEL, Phosphorus - based flame retardancy mechanisms,old hat or a starting point for future development , 10,3, 4710-4745 , 2010

16- MURIEL RAKOTOMALALA, SEBASTIAN WAGNER and ANFREDORING, Recent developments in halogen free flame retardants for epoxy resins for electrical and electronic applications ,3,4300-4327,2010.

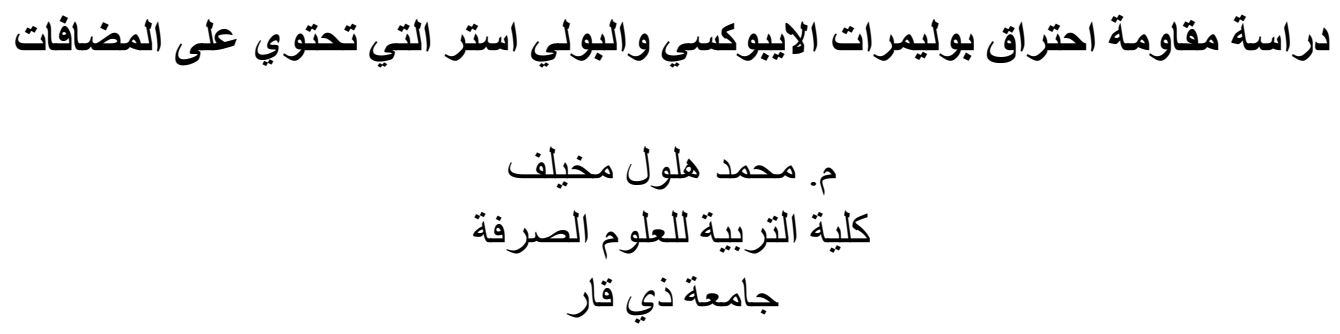

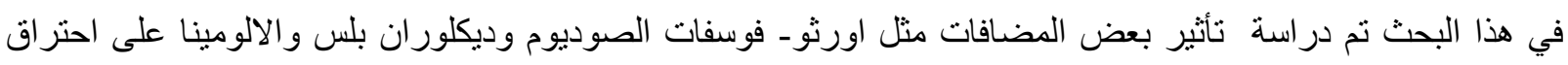

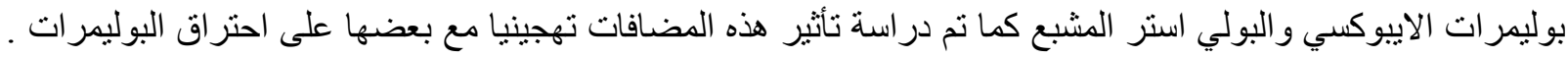

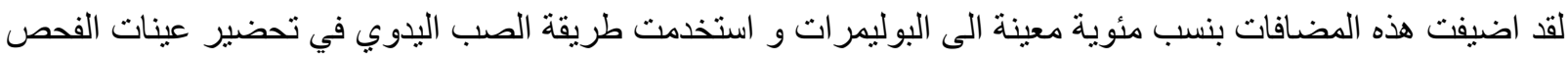

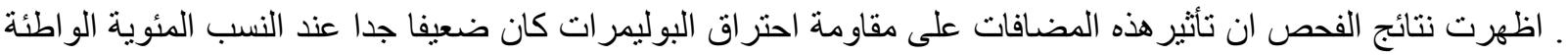

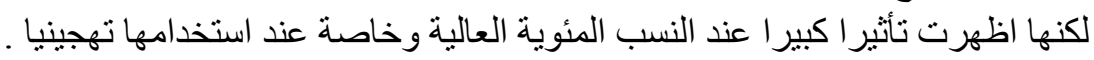

